\title{
Histopathology
}

Handling and Reporting of Transurethral Resection Specimens of the Bladder in Europe: A Web-Based Survey by the European Network of Uropathology (ENUP)

\begin{tabular}{|r|l|}
\hline Journal: & Histopathology \\
\hline Manuscript ID: & HISTOP-01-10-0056.R1 \\
\hline Manuscript Type: & Original Article \\
\hline Keywords: & $\begin{array}{l}\text { Pathology, TURB, Bladder Neoplasms, Reporting, ransurethral } \\
\text { resection }\end{array}$ \\
\hline \multicolumn{2}{|l}{} \\
\hline
\end{tabular}

$\$$ Manuscript Central 


\section{Handling and Reporting of Transurethral Resection Specimens of the Bladder in Europe: A Web-Based Survey by the European Network of Uropathology (ENUP)}

$1^{*}$ Antonio Lopez-Beltran, ${ }^{2}$ Ferran Algaba, ${ }^{3}$ Daniel M Berney, ${ }^{4}$ Liliane Boccon-Gibod, ${ }^{5}$ Philippe
Camparo, ${ }^{6}$ David Griffiths, ${ }^{7}$ Gregor Mikuz,${ }^{8}$ Rodolfo Montironi, ${ }^{9}$ Murali Varma, ${ }^{10 *}$ Lars Egevad

${ }^{1}$ Unit of Anatomic Pathology, Cordoba University Medical School, Cordoba, Spain

${ }^{2}$ Dept of Pathology, Fundación Puigvert-University Autonomous, Barcelona, Spain,

${ }^{3}$ Dept of Molecular Oncology and Imaging, Institute of Cancer, Queen Mary University of

London, London, United Kingdom

${ }^{4}$ Dept of Pathology, , Hôpital Armand Trousseau, Assistance Publique, Hôpitaux de Paris,

Université Pierre et Marie Curie, Paris, France

${ }^{5}$ Service d'anatomie et cytologie pathologiques, Hopital Foch, Paris, France

${ }^{6}$ Dept of Pathology, University Hospital of Wales, Cardiff, United Kingdom

${ }^{7}$ Institute of Pathology, Medical University, Innsbruck, Austria

${ }^{8}$ Institute of Pathological Anatomy and Histopathology, School of Medicine, Polytechnic

University of the Marche Region, Ancona, Italy

${ }^{9}$ Dept of Pathology, University Hospital of Wales, Cardiff, United Kingdom

${ }^{10}$ Dept of Pathology, Karolinska University Hospital, Stockholm, Sweden

*These authors contributed equally to this publication

Key Words: Pathology, TURB, Bladder Neoplasms, Reporting, transurethral resection

Running Title: Transurethral Resection of Bladder in Europe 


\title{
Word count:
}

\author{
Abstract: 198 \\ Article (excluding abstract, legends and references): 2052
}

Address of correspondence: Prof. Dr. Antonio Lopez-Beltran, Unit of Anatomical Pathology, Faculty of Medicine, E-14004 Cordoba, Spain; phone 34957218992; fax 34957218229; e-mail: em1lobea@uco.es or Dr. Lars Egevad, Dept of Pathology, Karolinska University Hospital, Stockholm, Sweden; phone +46-8-51775492 ; email: lars.egevad@ki.se 


\begin{abstract}
AIMS: The collection of information about European practices on handling and reporting of transurethral resection specimens of the bladder (TURB).

METHODS AND RESULTS: The European Network of Uropathology is a communication network that includes 335 pathology laboratories in 15 West European countries. A web-based questionnaire was answered by $52.2 \%$ of members. Some routines were adopted by a majority: formalin fixation $(92.5 \%)$, separate containers for tumour and resection base $(72 \%)$ and embedding of the entire specimen $(60 \%)$. Cancer along/in adipose tissue would be reported as pT3a by $19.5 \%$ and non-invasive urothelial carcinoma in prostatic ducts/glands as pT4a by 16.1\%. Papillary urothelial neoplasia of low malignant potential (PUNLMP) is recognized by $72.6 \%$ but rarely reported. Immunohistochemistry is rarely or sometimes used for diagnosing bladder cancer by 91.7\%, and most frequently used markers are CK20 (76.9\%), CK7 (66.7\%) and Ki67 (38.8\%). Only $24.8 \%$ report prognostic markers with Ki67 (84.4\%) and p53 (64.4\%) being most common. Only 50.9\% use the ISUP 1998/WHO 2004 grading system followed by WHO $1973(43.4 \%)$ and WHO $1999(31.4 \%)$.
\end{abstract}

CONCLUSIONS: There is still variability in routine practice and a need for standardization of methodologies. These results may be helpful when judging what recommendations are reasonable to issue. 


\section{Introduction}

The practice of pathology changes continuously parallel with the development of medicine. Increasing knowledge and new technologies affect our approach to handling, processing, assessment and reporting of specimens. Studies on how uropathology is practiced among general pathologists in North America and among uropathology experts globally have been published, ${ }^{1-4}$ but no large-scale European studies have been done. ${ }^{1}$ The uropathology group of the European Society of Pathology recently initiated a European Network of Uropathology (ENUP). ${ }^{1,5}$ The purposes were to get a route for dissemination of relevant information about uropathology such as guidelines, consensus documents and society information about meetings, courses and grants and to serve as a hub for research collaborations. ${ }^{5}$ The aim was also to conduct web-based surveys on how uropathology is practiced in Europe (e.g. handling and reporting of various specimens). ${ }^{1,5}$ We here present the results of the first survey study on handling and reporting of transurethral resection specimens of the bladder (TURB) in Europe.

\section{Materials and Methods}

ENUP was founded by recruiting uropathologists from pathology departments in Western Europe . ${ }^{1,5}$ In January 2008, ENUP had members from 335 laboratories in 15 countries (Table 1). A web-based anonymous questionnaire was launched with 40 questions about routines for handling and reporting of TURB specimens. All questions were of multiple-choice type, but in some the respondents were also allowed to give other alternatives or to write comments. An invitation to participate in the survey was circulated by email to all ENUP members in June 2008 and reminders were sent 3 times until the survey closed in September 2008. To avoid ambiguity, the questionnaire was written by a multinational group of dedicated pathologists and then 
circulated and further revised through several cycles. The final survey composed in survey monkey was checked on line by the group before launch. This served as pilot or pre-circulation test with request for extensive feedback.

\section{Results}

The overall response rate was $52.2 \%(175 / 335)$ of the ENUP members. The geographic distribution of the respondents is shown in Table 1. Of pathologists who replied, $44.3 \%(77 / 174)$ worked at a university (academic) hospital, 50.6\% (88/174) in a community (public healthcare) hospital, $4.6 \%(8 / 174)$ in private healthcare and $0.6 \%(1 / 174)$ in another type of institution. The total number of TURB specimens processed per year in the laboratory of the respondents varied widely: <101 in $13.5 \%$ (23/170), $101-200$ in $34.7 \%$ (59/170), $201-300$ in $21.8 \%$ (37/170), $301-$ 500 in $20.6 \%(35 / 170), 501-1000$ in $7.6 \%(13 / 170)$ and $>1000$ in $1.8 \%(3 / 170)$.

Some routines were adopted by a large majority: formalin fixation $(92.5 \%, 160 / 173)$, separate containers for tumour and resection base $(72 \%, 126 / 175)$, embedding the entire TURB specimen $(60 \%, 105 / 175)$. Fresh tissue for research purposes was harvested in at least some cases by $16.7 \%$ (29/174) (Tables 2 and 3). A lab technician usually grossly examines the TURB specimens in $50.9 \%(89 / 175)$ (Table 2). In addition to the main container of TURB with tumour, separate containers to assess the adjacent urothelium or flat lesions are sometimes submitted as single $47.1 \%(81 / 172)$ or multiple samples in $35.5 \%$ (61/172) (Table 3).

Table 4 shows how European uropathologists grade bladder tumours; only 51.7\% (89/172) of respondents report the ISUP 1998/WHO 2004 grading system. Among the other grading systems applied are the WHO $1973(43.6 \%, 75 / 172)$ and the WHO 1999 (32.0\%, 55/172). However, multiple grading systems are used by several responders with the ISUP 1998/WHO 2004 and the WHO 1973 being most commonly applied. The entity papillary urothelial neoplasm of low grade 
malignant potential (PUNLMP) is recognized by $72.6 \%$ of the respondents but more than half (89/172) rarely report it.

The TNM stage (either 1997 or 2002) of the tumour was reported by $74.7 \%$ (127/170) of respondents (Table 5). In stage pT1, substaging of the level of invasion is performed by $36.8 \%$ $(63 / 173)$ and this is usually $(68.2 \%, 45 / 66)$ based on the presence of muscularis mucosae (Table 5). Most respondents $(74.9 \%, 128 / 171)$ report on whether detrusor muscle (muscularis propria) is present or absent in the specimen (Table 5).

Table 5 also shows how European uropathologists report on TURB specimens with cancer. There is some variation on how the stage of cancer infiltrating thick muscle bundles suggesting muscularis propria is reported, that is pT2 (28.5\%), pT2, at least $(26.2 \%)$, pT2a (1.2\%) pT2a, at least $(26.2 \%)$ or just as a descriptive note $(18.0 \%)$. Also, $19.5 \%(33 / 169)$ of respondents would report cancer along/in adipose tissue as pT3a, and the presence of non-invasive urothelial carcinoma in prostatic ducts/glands would be considered pT4a by $15.9 \%$ (Table 6).

In addition, microscopic vascular-lymphatic involvement is routinely reported by $89.3 \%$ (150/168), and the tumour growth pattern (infiltrating, expansive, papillary or mixed forms) is reported by $42.6 \%(72 / 169)$, mainly as a descriptive note. Morphologic variants of bladder cancer are reported by $88.6 \%$ (148/167). Immunohistochemistry is rarely or sometimes used by $91.7 \%$ as an adjunct when diagnosing bladder cancer, and markers most frequently used are CK20 (76.9\%), CK7 (66.7\%) and Ki67 (38.8\%). Only $24.8 \%$ of respondents report prognostic markers for bladder cancer with $\mathrm{Ki} 67(84.4 \%)$ and p53 (64.4\%) being the most common among them. An image is routinely attached to the pathology report by $1.8 \%$. The most common method is a microscopic image $(83.3 \%, 5 / 6)$.

\section{Discussion}

In recent years consensus documents and guidelines have been published on how to handle, 
assess and report TURB specimens. These documents originate from the College of American Pathologists, European Association of Urology and the European Society of Pathology ${ }^{6-9}$. Little has been known about how these documents are applied by practicing pathologists. Yet, to our knowledge no systematic studies have been performed outside North America on how TURB specimens are routinely processed or reported by practicing pathologists.

There are several difficulties with studies on how pathology is practiced. ${ }^{1,5}$ The results tend to be biased because the participants are often recruited among leading experts from academic institutions. Our aim was to cover as many pathology departments as possible, including academic and non-academic, large and small, private and public laboratories. The purpose of doing survey studies is not primarily to find out how pathology should be practiced. Consensus documents should preferably be based on evidence rather than on majority decisions only. However, it is essential to know to which extent pre-existing documents are actually followed. It is also useful to know which routines are already commonplace so realistic recommendations can enter into consensus documents while others may be delayed until more information has been distributed. If the gap between guidelines and current practice becomes too wide, the credibility of the guidelines will decrease. ${ }^{1-15}$

The current survey shows that some routines for handling of TURB specimens are already adopted by a majority of pathologists, such as formalin fixation, separate containers for tumour and resection base or embedding the entire specimen. ${ }^{6-10}$ Some of these are recommended in consensus documents or guidelines such as those developed by the College of the American Pathologists, European Association of Urology and the European Society of Pathology. ${ }^{1-10}$ The ENUP survey also shows that sampling fresh tissue for research purposes is not a common practice in Europe with less than $17 \%$ institutions occasionally harvesting fresh tissue. Also, a lab technician grossly examines the TURB specimens in $50.9 \%$ of institutions which implies that this 
practice is more common in Europe when compared with North America. ${ }^{6-10}$ Likewise, the practice of submitting separate containers to assess the adjacent urothelium or flat lesions which has been suggested to represent a standard of care is not a uniform practice in Europe since it is only performed 'sometimes' by $82.6 \%$ of respondents. One of the most interesting findings is how European uropathologists grade bladder tumours in TURB specimens. ${ }^{16-21}$ Only $51.7 \%$ of respondents report the ISUP 1998/WHO 2004 grading system followed by the WHO 1973 (43.6\%) and the WHO 1999 (32.0\%) grading systems. However, multiple grading systems are used by several responders with the ISUP 1998/WHO 2004 and the WHO 1973 being most commonly applied. This agrees with the proposals by the European Association of Urology and the European Society of Pathology supporting the reporting of both ISUP 1998/WHO 2004 and WHO 1973 grade until more experience with the former grading system is available. ${ }^{6,7}$ Likewise, it was notable that almost a third of respondents use WHO 1999 for grading bladder tumours even though the use of this system is not recommended by any of the urological/pathological societies or current guidelines. The entity PUNLMP is recognized by $72.6 \%$ of the respondents but half of them rarely report it. ${ }^{14,16,18,20}$ This is in line with the current controversy on the use of this entity as a valid term in daily practice of bladder pathology, but at the same time shows that reporting PUNLMP approaches the level reached in North America.9, 14, 16, 18, 20,21 Following current recommendations, the TNM staging system of the tumour was reported by most respondents. pT1 substaging, which is largely based on the presence of muscularis mucosae, is a limited practice in Europe but follows the current recommendations since available guidelines only include pT1 substaging as an option in the final diagnostic report. ${ }^{14,10,22}$ Also, with the purpose of giving some feedback to the surgeon, most respondents report on whether detrusor muscle (muscularis propria) is present or absent in the specimen following international recommendations. ${ }^{6-10}$ For reporting of muscle invasive cases, there is some variation on how 
thick muscle bundles (suggesting muscularis propria) are reported when cancer is present. The current guidelines support that this is reported as pT2 at least, but this is fulfilled only by $26 \%$ of respondents. This probably indicates that more educational efforts are needed on how to report muscularis propria invasion by tumours in TURB specimens.

Also of potential clinical importance is the fact that $19.5 \%$ of respondents would report cancer along/in adipose tissue as pT3a, a practice not recommended in recent guidelines and by the TNM staging system_.Partial or total cystectomy is required to make such a diagnosis since fat tissue is known to be present within the bladder wall including the lamina propria/submucosa. ${ }^{6-10}$ This finding could however be related to hidden negative effects of centralisation of major surgery in some places.

Another controversial area of interest in the ENUP survey results is the fact that the presence of non-invasive urothelial carcinoma in prostatic ducts/glands would be considered pT4a by $15.9 \%$. This is clearly at variance with available guidelines and represents an important staging pitfall with potentially clinically significant consequences in patient care; likewise, since prostate extension from bladder cancer is better defined in the current TNM (7th edition) which states "T4 disease defined as including prostatic stromal invasion directly from bladder cancer. Subepithelial invasion of prostatic urethra will not constitute T4 staging status", it would be expected that T4a related staging pitfalls will be largelly reduced in near future.

Thus, the ENUP survey results suggest that there is a need of educational activities in specific areas relevant to clinical practice. However, it may also be considered that the respondents have complied with local guidelines that are not in line with contemporary international practice. In the future, such a lack of compliance with mainstream recommendations could be decreased by dissemination of international guidelines. The ENUP results seen in this report could additionally help to achieve more synchronicity between "local" and European guidelines 
at the EU level. Another problem with international consensus studies is that there may be a linguistic barrier that makes the interpretation of questions more difficult than in national questionnaires. Terminology may differ between countries and does not always translate easily to English. Furthermore, the linguistic skills of the respondents may be highly variable. Therefore, the observed differences in practices might also be the result of different interpretations of an ambiguous question. Thus, results have to be interpreted with some caution.

Other issues such as the way uropathologists routinely report on microscopic vascular-lymphatic involvement, the tumour growth pattern or morphologic variants of bladder cancer, or the way immunohistochemistry is applied follows international standards.

In conclusion, the ENUP survey shows how TURB specimens are handled and reported in Europe with most practices already standardized when compared with the practice in North America. However, the survey also identifies areas in which improvement is needed; in particular efforts should be directed to better reporting staging issues related to invasion of the muscularis propria, fat tissue and prostate tissue chips seen at time of TURB.

\section{Acknowledgement}

We would like to thank all ENUP members for their support and for taking their time to fill out the survey

\section{Reference}

1. L Egevad, F Algaba, D M Berney, L Boccon-Gibod, D F Griffiths, A Lopez-Beltran, G Mikuz, M Varma, R Montironi. Handling and reporting of radical prostatectomy specimens in Europe: a web-based survey by the European Network of Uropathology (ENUP). Histopathology. 2008; 53; 333-339.

2. Egevad L, Allsbrook WC Jr, Epstein JI. Current practice of Gleason grading among genitourinary pathologists. Hum. Pathol. 2005; 36; 5-9. 
3. Egevad L, Allsbrook WC, Epstein JI. Current practice of diagnosis and reporting of prostatic intraepithelial neoplasia and glandular atypia among genitourinary pathologists. Mod. Pathol. 2006; 19; 180-185.

4. Egevad L, AllsbrookWCJr, Epstein JI. Current practice of diagnosis and reporting of prostate cancer on needle biopsy among genitourinary pathologists. Hum. Pathol. 2006; 37; 292-297.

5. Egevad L, Algaba F, Berney DM, Boccon-Gibod L, Griffiths DF, Lopez-Beltran A, Mikuz G, Varma M, Montironi R. European Network of Uropathology.The European Network of Uropathology: a novel mechanism for communication between pathologists. Anal. Quant. Cytol. Histol. 2009; 31; 90-5

6. Lopez-Beltran A, Bassi PF, Pavone-Macaluso M, Montironi R. Handling and Pathology Reporting of Specimens with Carcinoma of the Urinary Bladder, Ureter, and Renal Pelvis. Eur. Urol. 2004; 45; 257-266

7. Lopez-Beltran A, Bassi PF, Pavone-Macaluso M, Montironi R. Handling and pathology reporting of specimens with carcinoma of the urinary bladder, ureter, and renal pelvis. A joint proposal of the European Society of Uropathology and the Uropathology Working Group. Virchows Arch. 2004; 445; 103-110

8. Amin MB, Srigley JR, Grignon DJ, Reuter VE, Humphrey PA, Cohen MB, Hammond ME Updated protocol for the examination of specimens from patients with carcinoma of the urinary bladder, ureter, and renal pelvis. Arch. Pathol. Lab. Med. 2003; 127; 1263-1279

9. Amin MB, Delahunt B, Bochner BH, Epstein JI, Grignon DG, Montironi R, Paner GP, Renshaw AA, Reuter VE, Srigley JR, Humphrey PA. Protocol for the Examination of Specimens from Patients with Carcinoma of the Urinary Bladder.

http://www.cap.org/apps/docs/committees/cancer/cancer_protocols/2009/UrinaryBladder_09prot ocol.pdf

10. Cheng L, Montironi R, Davidson DD, Lopez-Beltran A. Staging and reporting of urothelial carcinoma of the urinary bladder. Mod. Pathol. 2009; 22; S70-S95

11. Hruban RH, Wetra WH, Phelps TH, Isacson C. Surgical pathology dissection. An illustrated guide. New York: Springer Verlag, 1996

12. Pavone-Macaluso M, Lopez-Beltran A, Aragona F, Bassi PF, Fitzpatrick JF. The pathology of bladder cancer: an update on selected issues. BJU Int. 2006; 98; 1161-1165

13. Mostofi FK, Davis CJ, Sesterhenn IA. World Health Organization International Histological Classification of Tumours. Histological Typing of Urinary Bladder Tumours. 2nd ed. Springer Verlag, Berlin Heidelberg, 1999

14. Eble JN, Sauter G, Epstein JI and Sesterhenn IA: Pathology and Genetics of Tumours of the Urinary System and Male Genital Organs. Lyon, IARC Press, 2004 
15. Mostofi FK, Sobin LH. Histologic typing of urinary bladder tumors. World Health Organization Geneva, Switzerland, 1973.

16. Epstein JI, Amin MB, Reuter VR, Mostofi FK. The World Health Organization/International Society of Urological Pathology consensus classification of urothelial (transitional cell) neoplasms of the urinary bladder. Bladder Consensus Conference Committee. Am. J. Surg. Pathol. 1998; 22;1435-1448.

17. Montironi R, Lopez-Beltran A, Scarpelli M, Mazzucchelli R, Cheng L. Morphological classification and definition of the benign, preneoplastic and non-invasive neoplastic lesions of the urinary bladder. Histopathology. 2008; 53; 621-633.

18. Jones TD, Cheng L. Papillary urothelial neoplasms of low malignant potential: evolving terminology and concepts. J. Urol. 2006; 175;1995-2003.

19. Malmstrom PU, Busch C, Norlen BJ. Recurrence, progression and survival in bladder cancer. A retrospective analysis of 232 patients with greater than or equal to 5-year follow-up. Scand. J. Urol. Nephrol. 1987; 21;185-195.

20. Lopez-Beltran A, Montironi R. Non-invasive urothelial neoplasms: according to the most recent WHO classification. Eur. Urol. 2004; 46;170-176.

21. Montironi R, Lopez-Beltran A, Scarpelli M, Mazzucchelli R, Cheng L. 2004 World Health Organization Classification of the Noninvasive Urothelial Neoplasms: Inherent Problems and Clinical Reflections. Eur. Urol. Suppl. 200 9; 8; 453-457

22. Lopez-Beltran A, Cheng L. Stage pT1 bladder carcinoma: diagnostic criteria, pitfalls and prognostic significance. Pathology. 2003; 35; 484-491 
Table 1. Countries participating in the European Network of Uropathology (ENUP) and in the TURB survey study.

\begin{tabular}{|c|c|c|c|c|}
\hline Country & $\begin{array}{c}\text { Number of } \\
\text { ENUP } \\
\text { members }\end{array}$ & $\begin{array}{c}\% \text { of } \\
\text { ENUP } \\
\text { members }\end{array}$ & $\begin{array}{l}\text { Number of } \\
\text { respondents }\end{array}$ & $\begin{array}{c}\% \text { of } \\
\text { respondents }\end{array}$ \\
\hline Austria & 7 & 2.0 & 3 & 1.7 \\
\hline Belgium & 17 & 5.0 & 12 & 6.8 \\
\hline Denmark & 14 & 4.2 & 7 & 4.0 \\
\hline Finland & 9 & 2.7 & 7 & 4.0 \\
\hline France & 41 & 12.2 & 19 & 10.8 \\
\hline Germany & 45 & 13.4 & 19 & 10.8 \\
\hline Ireland & 5 & 1.5 & 1 & 0.5 \\
\hline Italy & 45 & 13.4 & 21 & 12.0 \\
\hline Netherlands & 22 & 6.6 & 11 & 6.2 \\
\hline Norway & 16 & 4.8 & 9 & 5.1 \\
\hline Portugal & 14 & 4.2 & 6 & 3.4 \\
\hline Spain & 18 & 5.4 & 12 & 6.8 \\
\hline Sweden & 27 & 8.0 & 14 & 8.0 \\
\hline Switzerland & 12 & 3.6 & 9 & 5.1 \\
\hline $\begin{array}{l}\text { United } \\
\text { Kingdom }\end{array}$ & 43 & 12.9 & 25 & 14.2 \\
\hline TOTAL & 335 & 100 & 175 & 100 \\
\hline
\end{tabular}

TURB means transurethral resection of bladder 
Table 2. Handling of TURB specimens (gross processing, description, and submission).

\begin{tabular}{|c|c|c|}
\hline Question & $\%$ & Number \\
\hline \multicolumn{3}{|l|}{ Who usually grossly examines the specimens } \\
\hline - Qualified medical pathologist & 30.9 & $54 / 175$ \\
\hline - A resident (trainee) pathologist & 18.3 & $32 / 175$ \\
\hline - A lab technician & 50.9 & $89 / 175$ \\
\hline \multicolumn{3}{|l|}{ Characteristics of submitted samples } \\
\hline $\begin{array}{l}\text { - Separate containers for tumour and } \\
\text { resection base }\end{array}$ & 72.0 & $126 / 175$ \\
\hline $\begin{array}{l}\text { - Tumour and resection base usually in the } \\
\text { same container(s) }\end{array}$ & 28.0 & $49 / 175$ \\
\hline \multicolumn{3}{|l|}{$\begin{array}{l}\text { Gross description (multiple alternatives may be } \\
\text { indicated) }\end{array}$} \\
\hline $\begin{array}{l}\text { - Weight of all submitted material (measured } \\
\text { at pathology lab }\end{array}$ & 53.4 & $93 / 174$ \\
\hline $\begin{array}{l}\text { - Weight of all submitted material (given by } \\
\text { the clinicians on the path request form) }\end{array}$ & 5.2 & $9 / 174$ \\
\hline $\begin{array}{l}\text { - Measurement of grouped material (e.g. main } \\
\text { axes in cm.) }\end{array}$ & 32.2 & $56 / 174$ \\
\hline $\begin{array}{l}\text { - Approximate estimation of volume (e.g. } \\
\text { millilitres, decilitres, tablespoons....) }\end{array}$ & 26.4 & $46 / 174$ \\
\hline - No measurement at all in the report & 6.9 & $12 / 174$ \\
\hline - Other (please comment) & 5.2 & $9 / 174$ \\
\hline
\end{tabular}


Table 3. Handling of TURB specimens (sampling characteristics)

\begin{tabular}{|c|c|c|}
\hline Question & $\%$ & Number \\
\hline \multicolumn{3}{|l|}{ How much of TURB specimens do you embed } \\
\hline - Total embedment always & 60.0 & $105 / 175$ \\
\hline - Total embedment sometimes & 26.3 & $46 / 175$ \\
\hline $\begin{array}{l}\text { - Partial embedment always (randomly } \\
\text { selected chips) }\end{array}$ & 2.9 & $5 / 175$ \\
\hline $\begin{array}{l}\text { - Partial embedment with selection "de } \\
\text { visum" or by "visual estimation" of chips } \\
\text { suspicious for including muscularis propria }\end{array}$ & 2.9 & $5 / 175$ \\
\hline - Other & 8.0 & $14 / 175$ \\
\hline \multicolumn{3}{|l|}{$\begin{array}{l}\text { How do you define the limit above which you apply } \\
\text { partial embedment? }\end{array}$} \\
\hline - Number of cassettes. & 68.7 & $46 / 67$ \\
\hline - Weight of tissue. & 23.9 & $16 / 67$ \\
\hline - Other method (specify) & 7.5 & $5 / 67$ \\
\hline \multicolumn{3}{|l|}{ In case of partial inclusion, which method is used } \\
\hline $\begin{array}{l}\text { - Percentage of submitted material (e.g. } 10 \% \\
\text { increments: } 10 \%, 20 \%, 30 \% \text { etc.) }\end{array}$ & 4.7 & $3 / 64$ \\
\hline - Number of cassettes $(1,2,3$, more $)$ & 59.4 & $38 / 64$ \\
\hline - Weight (gr) & 21.9 & $14 / 64$ \\
\hline - Other criteria (please specify) & 14.1 & $9 / 64$ \\
\hline $\begin{array}{l}\text { In addition to the main container of TURB with } \\
\text { tumour, do you receive separate containers to assess } \\
\text { the adjacent urothelium or flat lesions }\end{array}$ & & \\
\hline $\begin{array}{l}\text { - A sample (one or a few biopsies) of adjacent } \\
\text { mucosa is always submitted }\end{array}$ & 5.8 & $10 / 172$ \\
\hline $\begin{array}{l}\text { - A sample(one or a few biopsies) of adjacent } \\
\text { mucosa is sometimes submitted }\end{array}$ & 47.1 & $81 / 172$ \\
\hline $\begin{array}{l}\text { Multiple samples (quadrants biopsies, other } \\
\text { mapping methods)of adjacent mucosa are } \\
\text { always submitted }\end{array}$ & 7.6 & $13 / 172$ \\
\hline $\begin{array}{l}\text { Multiple samples (quadrants biopsies, other } \\
\text { mapping methods)of adjacent mucosa are } \\
\text { sometimes submitted }\end{array}$ & 35.5 & $61 / 172$ \\
\hline - When samples of adjacent urothelium are & 12.8 & $22 / 172$ \\
\hline
\end{tabular}




\begin{tabular}{|c|c|c|}
\hline submitted, this includes urethral mucosa & & \\
\hline $\begin{array}{l}\text { - No, adjacent mucosa is not submitted in a } \\
\text { separate container }\end{array}$ & 20.3 & $35 / 172$ \\
\hline
\end{tabular}


Table 4. Pathologic grade.

\begin{tabular}{|c|c|c|}
\hline Question & $\%$ & Number \\
\hline \multicolumn{3}{|l|}{ How do you grade urothelial tumours } \\
\hline - WHO 1973 (papilloma, Grade 1,2 and 3) & 43.6 & $75 / 172$ \\
\hline $\begin{array}{l}\text { - ISUP 1998, i.e. WHO } 2004 \text { (papilloma, } \\
\text { PUNLMP, LG, HG) }\end{array}$ & 51.7 & $89 / 172$ \\
\hline $\begin{array}{l}\text { - WHO } 1999 \text { (papilloma, PUNLMP, Grade 1, } \\
2 \text { and 3) }\end{array}$ & 32.0 & $55 / 172$ \\
\hline - Others & 4.7 & $8 / 172$ \\
\hline \multicolumn{3}{|l|}{ Do you report PUNLMP } \\
\hline - Yes & 20.9 & $36 / 172$ \\
\hline $\begin{array}{l}\text { - } \quad \text { Yes, rarely }(<10 \% \text { of all non-invasive } \\
\text { - } \quad \text { papillary tumours })\end{array}$ & 51.7 & $89 / 172$ \\
\hline - No & 27.3 & $47 / 172$ \\
\hline
\end{tabular}

WHO means World Health Organization; ISUP, International Society of

Urological Pathologists; PUNLMP, Papillary Urothelial Neoplasia of Low

Malignant Potential 
Table 5. Pathologic staging.

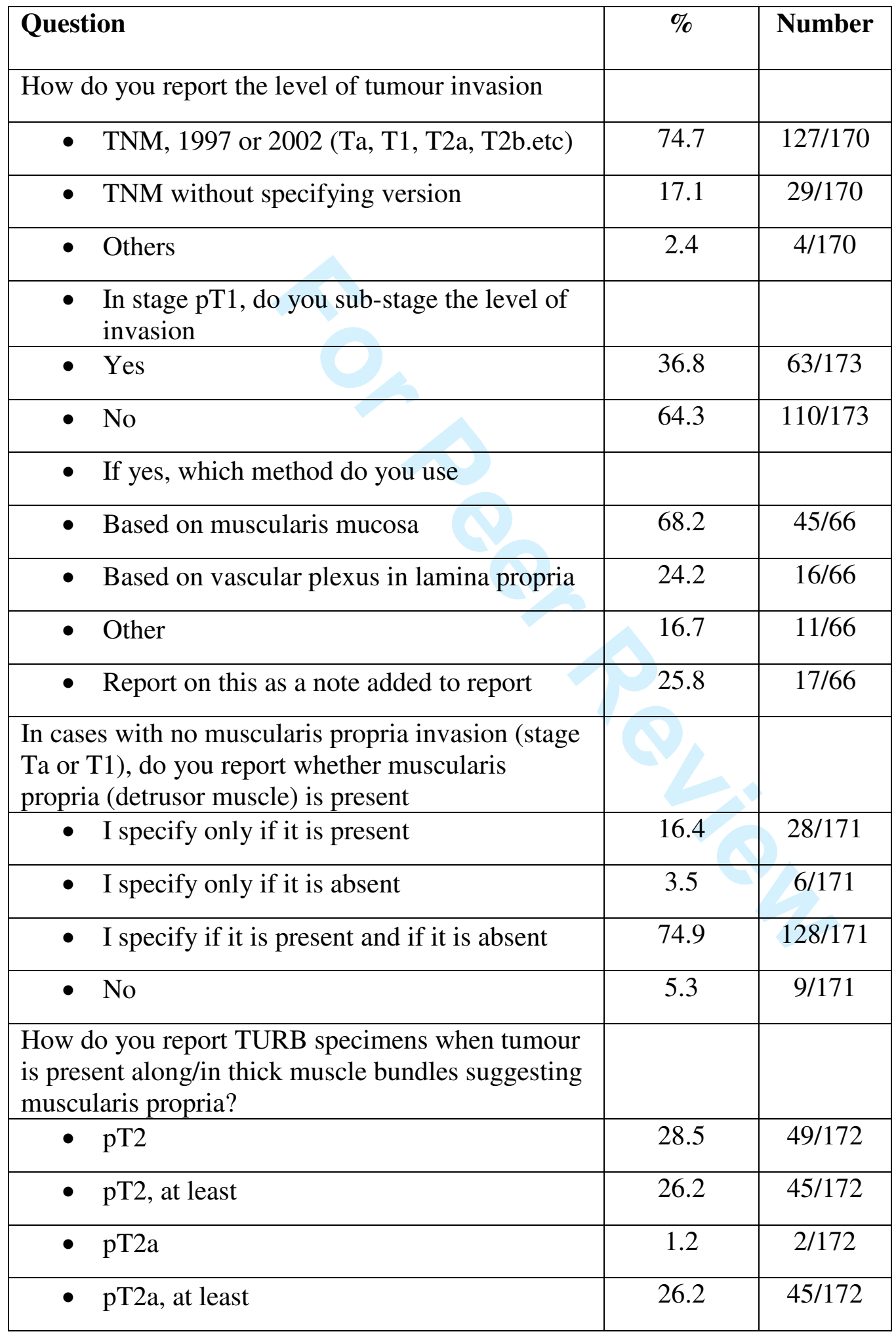




\begin{tabular}{|c|c|c|}
\hline$\bullet \quad$ pT2b or pT2b, at least & 0 & $2 / 172$ \\
\hline$\bullet \quad \begin{array}{l}\text { Descriptive (muscularis propria involved by } \\
\text { tumour) }\end{array}$ & 18.0 & $45 / 172$ \\
\hline $\begin{array}{l}\text { How do you report when tumour is present along/in } \\
\text { fat tissue }\end{array}$ & 60.4 & $102 / 169$ \\
\hline$\bullet \quad$ I report it as fat tissue present & 20.1 & $34 / 169$ \\
\hline$\bullet \quad$ I do not report it & 19.5 & $33 / 169$ \\
\hline$\bullet \quad$ I report it as extravesical extension (pT3a) & & \\
\hline
\end{tabular}

TNM means tumour node metastasis stage classification 
Table 6. Reporting on TURB specimens with cancer in prostate chips

\begin{tabular}{|c|c|c|}
\hline Question & $\%$ & Number \\
\hline \multicolumn{3}{|l|}{$\begin{array}{l}\text { Do you report when urothelial carcinoma is present } \\
\text { in prostate chips }\end{array}$} \\
\hline - Yes (always) & 96.5 & $164 / 170$ \\
\hline - Sometimes & 3.5 & $6 / 170$ \\
\hline \multicolumn{3}{|l|}{$\begin{array}{l}\text { When you report urothelial carcinoma involvement } \\
\text { of prostate chips, do you specify the type of } \\
\text { prostate involvement in your report? }\end{array}$} \\
\hline - Yes & 85.2 & $144 / 169$ \\
\hline - No & 14.8 & $25 / 169$ \\
\hline \multicolumn{3}{|l|}{$\begin{array}{l}\text { Which pT stage would you assign to a case where } \\
\text { you find prostate chips with invasive urothelial } \\
\text { carcinoma growing in the prostatic stroma }\end{array}$} \\
\hline - $\mathrm{pTa}$ & 0 & $0 / 158$ \\
\hline - $\mathrm{pT} 1$ & 0.6 & $1 / 158$ \\
\hline 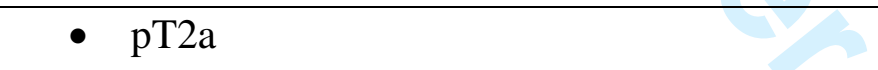 & 6.3 & $10 / 158$ \\
\hline - $\quad \mathrm{pT} 2 \mathrm{~b}$ & 0 & $0 / 158$ \\
\hline - $\quad \mathrm{pT} 3 \mathrm{a}$ & 2.5 & $4 / 158$ \\
\hline - $\quad \mathrm{pT} 3 \mathrm{~b}$ & 0.6 & $1 / 158$ \\
\hline - $\quad \mathrm{pT} 4 \mathrm{a}$ & 74.1 & $117 / 158$ \\
\hline - $\quad \mathrm{pT} 4 \mathrm{~b}$ & 1.3 & $2 / 158$ \\
\hline - Other & 14.6 & $23 / 158$ \\
\hline
\end{tabular}

